\title{
Trabalho escravo e trabalho livre (Origens históricas do capital)
}

DALE TOMICH

Traduçâo de LUIZA FRANCO MOREIRA

DALE TOMICH é prolessor do Departamento de Sociologia da Universidade de Nova York/Binghamton (Centro de Estudos Fernand Braudel) e autor de Slavery in the Circuit of Sugar

(The Johns Hopkins University

Piess)

1 Para uma discussho mais goral dos problemas motodolbogicos en volvidos no exame da transiçấo do foudalismo ouropeu ao capita. lismo mundial, vor mou artigo " Rapporti Sociali di Produrione Morcato Mundinlo nol dibattito Reconte sulla Transizione dal Fou dalismo al Capitalismo", in Studi Storici, 3 (1980), 539-564.

2 A respeito deste ponto, vet Kart Marx, Capital, L. Now York, 1977. p. 925 .
O proposito deste ensaio é investigar as origens do capital, considerado como uma relaçâo social mundialmente estruturada em que a valorizaçăo Ł possível, através de um exame da escravidão nas Américas, do trabalho assalariado na Europa e da circulaçăo de mercadorias em escala global. Tomadas em conjunto, estas relaçōes são elementos cruciais nos processos históricos constituindo a formação e subse. qüente transformaçâo da economia mundial capitalista. Este ensaio tenta explorar os problemas implícitos no desenvolvimento de um quadro analítico adequado para a compreensão dos processos históricos que compócm a acumulạ̧ăo de capital e a luta de classes em escala mundial(1). Aqui se enfatizam as formas de dominaçăo ne. cessariamente acarretadas pelo desenvolvimento histórico da produçấo capitalista de mercadorias. A forma específica de exploração da produçâo capitalista de mercadorias e tanto precedida e condicionada pela dominaçấo política, quantọ pressupōe tal dominaçăo como parte do processo de sua reproduçăo. Dessa maneira, a dominaçăo precisa ser compreendida para que se compreenda a exploraçäo. Contudo, há um outro lado da história do desenvolvimento capitalista - as lutas dos produtores diretos contra a exploração c a dominação social e política, assim como a circulaçăo dessas lutas - que apenas pode ser sugerido; já que a análise dessas lutas e de seu papel na transformação da cconomia mundial requer um exame das conjunturas políticas e das mediaçốes políticas dessas relaçôes que ultrapassaria o âmbito deste texto.

Num trecho bem conhecido do Capttal, ao encerrar seu relato da gênese do capitalista inclustrial, Marx contrapốe analiticamente " a escravidăo velacla dos assalariados na Europa " a " escravidâo desvelada do Novo Mundo ", ao mesmo tempo em que enfatiza sua interdependência e coexistência histórica(2). Mas esta idéia, ainda que sugestiva $e$ inovadora, não se encontra desenvolvida. Para Marx, trabalho escravo e trabalho assalariado formam os extremos opostos da produção de mercadorias $\mathbf{e}$ da dominação de classe. São, ao mesmo tempo, as mais semelhantes e as mais dessemelhantes dentre as formas de trabalho social discutidas em sua obra. Contudo, o propósito desse autor nảo é escrever a bistóría do desenvolvimento do capitalismo. Marx se interessa principalmente $\mathrm{cm}$ expor as formas de exploração e dominaçấo de classe veladas pela relação capital-trabalho assalariado. Em sua obra, a freqüente justaposição de escravidão e trabalho assalariado via de regra serve para iluminar as características específicas da relação capital-trabalho assalariado. Marx se preocupa primeiramente com a transformação das relaçôes e forças produtivas na Europa, desde a cooperação simples, passando pela manufatura, até a indústria moderna. Nấo traz para o centro de sua atenção a economia mundial enquanto tal ou as transformaçôes concomitantes do trabalho social no Novo Mundo. $\lambda$ parte algumas observaçōes sugestivas, Marx nem examina os processos históricos concretos do desenvolvimento do capitalismo $\mathrm{cm}$ sua relaçáo $\mathrm{com}$ a escravidăo, nem analisa sistematicamente a escravidāo enquanto tal na cconomia mundial capita. lista. Este ensaio se propōe a examinar justamente esta relaçăo entre o trabalho 
de que modo o feudalismo criou tanto a forma de produção de mercadorias em que o produtor retém a posse dos meios de produçáo quanto o mercado como forças que conduziram a sua própria dissoluçāo. Entretanto, pouca atenção foi dedicada a maneira pela qual o feudalismo produziu também a escravidão no Novo Mundo como parte do processo de sua dissolução; ou para como a escravidăo, por sua vez, contribuiu para a formação do trabalho assalariado. Assim, no contexto deste ensaio os problemas centrais serăo estes: compreender como a escravidão, enquanto precondição da produção capitalista, surgiu de dentro do modo de produçáo feudal; $\mathrm{e}$ entender como a mesma escravidão contribuiu tanto para a transição para o capitalismo quanto para a ruptura com a organização anterior da sociedade. É necessário entender o papel da escravidão no Novo Mundo dentro do movimento histórico em direção à forma capitalista de produção $\mathrm{e}$ à emergência do trabalho assalariado, e ao mesmo tempo mostrar a relação da escravidão com o capitalismo desenvolvido.

\section{I- O FEU DAIISMO EUROPEU E OS FUNDAMENTOS DO M E R C A D O M N D I A L}

O mercado mundial durante o periodo de acumulação originária é uma unidade que abrange e ultrapassa todos os capitais particulares. Esse mercado abarca e pressupốe uma divisão internacional do trabalho compreendendo uma variedade de formas nảo-assalariadas da produçẩo de mercadorias, que foram as precondiçốes históricas para a gênese da forma assalariada(5). Estas formas não-assalariadas de trabalho são expressas e mediadas pelo mercado munclial, que manifesta o caráter sistêmico do capital e do processo de acumulação como um todo, para além de qualquer capital nacional singular ou da mera soma de capitais nacionais. $\mathbf{A}$ transiçâo para o capitalismo refere-se a totalidade dessas relaçốes sociais expressas no nivel do mercado mundial. É um processo global, que inclui todas as relaçốes sociais de produção, distribuição, troca e consumo, as quais ao se desenvolverem constituem a totalidade da produçâo e reproduçâo do capital(6). Ainda que a emergencia da relaçâo capital-trabalho assalariado constitua o foco da transição para o capitalismo, o âmbito do processo histórico do desenvolvimento do capitalismo é definido pelo mercado mundial, e pressupốe a organização do trabalho social em escala mundial. O capital só pode se desenvolver adequadamente em escala mundial, e o trabalho assalariado emergiu como o resultado da concentração de atividades de produção e troca $\mathrm{em}$ certos pontos dessa rede de relações econØmicas. O conjunto destes processos - não apenas as regiōes onde o trabalho assalariado predomina - define e cria as fronteiras da economia mundial no espaço e no tempo.

O pensamento marxista convencional sustenta que a produção para troca nấo é suficiente para caracterizar o capitalismo, e que o crescimento do mercado mundial não é o fator principal da transição ao capitalismo. Não a troca, mas a "solidez e estrutura interna " do antigo modo de produçẩ(7) explicam o desenvolvimento de um novo modo de produção. Após estabelecer a validade metodológica deste insight, partidários desta visão reificam as categorias conceituais e revertem ao tratamento do capitalismo como um fenômeno nacional. Contudo, como propóem Baran, Frank, Amin, Wallerstein e outros, o desenvolvimento capitalista náo é uma ocorrência nacional ou européia, mas deve ser entendido como um fenômeno mundial. Mais ainda, a posição convencional tem mostrado a tendência de considerar o mercado mundial como um fenômeno secundário ou periférico, e tem feito recair o foco princípal da análise sobre relações de produção e capitais nacionais.

Em contraste, a linha de raciocínio seguida aqui considera dinâmico o mercado mundial nessa instância particular, porque este tanto se localiza nas relaçōes de classe que the determinam a importância real, especifica, como lhes dá expressáo; aqui, o mercado mundial cria condiçôes para a transição à produção capitalista durante o período de acumulação originária. Nesta perspectiva, o mercado mundial não é considerado um epifenômeno, nem abstraído como a única força dinâmica da historia - um "primeiro motor " externo como no debate Dobb-Sweezy - mas é gerado, ele, propriamente dito, das contradiçôes do modo de produção feudal. Assim, as origens do capital e da transição para o capitalismo encontram-se nas relaçốes sociais do feudalismo. É esta especificidade que nos permite compreender a recomposiçāo e a transformaçâo quantitativa e qualitativa da divisão internacional do trabalho e do mercado mundial, e assim perceber o caráter que se desenvolve historicamente do próprio capital.

Ver Kart Marx, Grundrisse, Har mondsworth, 1973, p. 278. Como Lukhics ontatiza, é preciso adrniti "a supremacia metodológica de totalidade face aos aspectos individuais". History and Class Cons ciousness, London, 1971, pp. 8-10

7 Marx, Capital, III, p. 332.

Ver Kart Marx, fiesults of the int diato Process of Production, apent dice de Capital, 1, New York. 1977. 
Na perspectiva proposta aqui, o problema histórico que deve nos ocupar abrange de um lado a transformação da totalidade das relaçōes de produção e troca numa economia mundial onde a organização direta da produção por meio do trabalho assalariado ainda não é dominante e, de outro, as condiçốes sob as quais esta economia mundial é reconstituída através da produção capitalista propriamente dita. Com o surgimento historico do trabalho assalariado, transformou-se a totalidade das relaçōes sociais do capital que abarcam a economia mundial. Todas as outras formas de trabalho social passaram a se relacionar com o trabalho assalariado, seja como pressuposto, seja como consequêencia. A acumulaçâo originária é, portanto, uma fase histórica no desenvolvimento da totalidade das relaçôes sociais capitalistas. Nấo se repete, nem poderia ser parte da acumulação e reprodução ampliada do capital. A transiçẫo para o capitalismo $\hat{e}$, assim, uma transição historicamente sin. gular do feudalismo europeu para o capitalismo mundial.

Com a formação do mercado mundial e da divisảo internacional do trabalho no século XVI, a produção e troca de mercadorias estendeu-se: de atividade esporádica, isolada e excepcional avançou até fornecer base adequada para o desenvolvimento da relação capital-trabalho assalariado. Contudo, o mercado mundial e a divisão internacional do trabalho durante o estágio da acumulação originária não foram de maneira nenhuma antecedentes lineares da moderna economia capitalista mundial, mas derivam sua especificidade dos processos do feudalismo europeu. $\mathrm{O}$ mercado mundial no período de acumulação originária foi tanto caracterizado quanto condicionado pela disjunção entre as condiçóes da produçấo $e$ as da troca de mercadorias no feudalismo europeu. A predominância das formas nảo-assalariadas de trabalho social indica que a produção não estava sob a dominação direta do capital e que o mercado mundial $e$ a divisão internacional do trabalho eram ambos organizados pelo capital mercantil independente(8). A expansão da produçấo $\mathrm{e}$ troca de mercadorias nesse mercado mundial foi simultaneamente desenvolvimento do modo feudal e condição para sua đissoluçẫo.

O conceito de capital mercantil expressa a relação contraditória entre produção e troca de mercadorias dentro da ordem social pré-capitalista européia e contra esta. O trabalho permanece preso a relaçôes sociais distintas daquelas entre trabalho assalariado e capital; e, o capital, até ser "liberado " no processo de acumulação originária, não exerce controle direto sobre o trabalho. Enquanto os produtores diretos permanecem na posse dos meios de produção e subsistência, apenas uma parte limitada do produto social toma a forma de mercadoria, e a ampliação da produção de mercadorias continua mediada, condicionada e limitada por relaçôes sociais de produçăo pré-capitalistas. É nesse sentido que devem ser entendidas as censuras contra a "vocação não-revolucionária " do capital mercantil, freqüentemente encontradas em textos marxistas. Não há algo como um imperativo categorico impedindo o capital mercantil de interferir na esfera da produção. Antes, enquanto o trabalho permanece preso a outras relaçôes, não-capitalistas, de produção, é necessariamente limitada a capacidade de transformar a produção que tem o capital mercantil enquanto portador da relação social do capital. $O$ capital não tem entâo uma relaçâo direta e imediata com o trabalho e permanece subordinado dentro da totaliclade maior das relaçóes sociais. Não que a classe mercantil urbana fosse incapaz de controlar e transformar a produção ou de introduzir inovaçôes técnicas; antes, relações sociais mais abrangentes limitavam o caráter e a extensão de tais esforços. O capital mercantil tinha de depender de outras classes, náo-capitalistas, para controlar e disciplinar o trabalho na produção e para garantir, através do estado, a reprodução da totalidade das relaçôes sociais que definem a existência do capital mercantil e fornecem as condiçốes sob as quais ele opera.

Sob estas condiçôes históricas específicas, o mercado permaneceu circunscrito por relaçôes sociais de produção pré-capitalistas. $\Lambda$ capacidade de o capital mercantil controlar e transformar a produçâo continuou restringida pela organização social de produção existente, da qual dependia o próprio capital mercantil. Este podia se expandir apenas na medida em que pudesse impor a forma da mercadoria ao produto do trabalho e interpor o mercado como elo entre os produtores. Quantitativamente, a acumulação de capital mercantil podia ocorrer através do aumento do volume da produção e troca de mercadorias, dentro dos limites prescritos pela totalidade das relaçóes sociais. De um ponto de vista qualitativo, porém, nas relaçốes de classe reinantes o comércio e o capital mercantil podiam se desenvolver somente 
através de privilégios jurídicos, monopólios, e restriçōes na produção e nos mercados

" (O) exclusivismo deve ser encarado como precondição para o desenvolvimento do capitalismo mercantil neste estágio (...) O mercado era uma presa limitada e sua 'captura' implicava na imposiçaode um monopólio de produção e troca face ao campo e face a intromissão de ciclades rivais. Enquanto o mercado dependeu da disparidade de preços entre esferas de produção nas quais os produtores não eram separados dos meios de produção e subsistência, o comércio existia somente nos interstícios do sistema, monopolizando a oferta de um conjunto limitado de bens, e era dependente de indulgência política: cra' mais uma estrutura de tributação do que uma estrutura de comérció" "(9).

Assim, o revolucionar das relaçôes de produção nâo constituiu a forma preponderante de expansão do capital mercantil. Esta expansão tomou antes a forma de um aumento na proporção do produto social que tomava a forma de mercadoria, e/ou de um expandir do próprio produto social total, dentro das relaçôes sociais existentes (por exemplo, via conquista, colonizaçâo, ou escravidão) e de um acumular de partes maiores dos excedentes comerciais já existentes através da extensão do privilégio de monopólio. Apesar da expansão da produção e troca de mercadorias no modo feudal, as relaçóes sociais de produção pré-capitalistas do campo europeu que foram condição para o desenvolvimento pleno do capital mercantil ao mesmo tempo constrangiam sua expansāo. O capital mercantil podia usar monopólios e privilégios para se desenvolver dentro dos limites desta ordem, mas não podia transcendê-la.

A posição especial e o desenvolvimento dinâmico da cidade como esfera corporativa urbana autônoma no feudalismo ocidental foi condiçăo para o desenvolvimento pleno do capital mercantil, como propóc John Merrington. A autonomia da cidade, escreve Merrington:

" ... era fundada na parcelização da soberania e limitada por esta; baseada na coincidência das relaçōes políticas e econômicas de subordinação/apropriação definidora do modo feudal. A existência de tal autonomia urbana corporativa, como um 'senhor coletivo' dentro de uma estrutura celular baseada na 'soberania em vários graus' foi precisamente o que encorajou o mais pleno desenvolvimento do capital mercantil na cidade feudal. Donde, $o$ 'capitalismo urbano' era tanto interno quanto externo ao modo feudal - ou, mais precisamente, o primeiro (aspecto) era condição do segundo... A 'oposição' de tais cidades (ao campo) era uma oposição de esferas económico-corporativas de soberania, o que deve ser encarado como um elemento tão interno ao feudalismo quanto a ascensảo e o de. clínio da economia senhorial (...) Longe de ser imóvel, e menos ainda exclusivamente 'rural', o feudalismo foi o primeiro modo de produção na história a permitir, justamente por sua ausência de soberania, que houvesse um lugar estrutural autônomo para a produçăo urbana $\mathrm{c}$ o capital mercantil "(10).

Idem, ibidem, p. 178. Ver tambern: Phillip Abrams, "Towns and Economic Grown", in Philip Abrams and E. A. Wrigley, eds., Towns in Socioties: Essays in Economic History and Historical Sociology. Cambridge, 1978, pp. 12-3. E ain da: Perry Anderson, Lineages of the Absolutist State, London, 1974. p. 408.

11 Merrington, "Town and Country" ${ }^{\prime \prime}$. p. 182

12 Ver A. B. Hibbent. "The Economic Policy of Towns", in Cambridge Economic History of Europe, III, Cambridgo, 1963, pp. 177-8

13 Merrington, op. cit., p. 179. Ver tam bém: Anderson, Lineages, p. 17.

14 Ver Merrington, op. cit. p. 179.

Desse modo, apesar de sua autonomia corporativa frente ao campo, a cidade feudal, longe de ser um centro livre de atividade capitalista, dependia do " cenário feudal " para os monopólios $\mathbf{c}$ as condiçōes jurídicas que definiam sua existência e defendiam seus privilégios (11). O capital mercantil dependia do poder jurídico e político do feudalismo para poder funcionar, $\mathrm{e}$ a existência da cidade feudal como um " senhor coletivo" era a expressão espacial desta relação econômico-política que punha a cidade em oposição ao campo (12). O crescimento urbano permaneceu " na mais intima correlaçâo com o crescimento da economia senhorial "(13). A ciclade feudal e o mercado urbano estavam, assim, contidos $\mathrm{em}$ relaçōes sociais pré-capitalistas e subordinados ao campo, que continuava a oferecer uma barreira para sua expansão.

$\Lambda$ autonomia urbana baseada na soberania parcelizada permitiu o pleno desenvolvimento tanto da oposição entre cidade e campo quanto da produçáo e troca de mercadorias no modo feudal(14). Entre os séculos XIV e XVI, desenvolveu-se na Europa Ocidental um conflito complexo entre produtores diretos, aristocracia rural 
e classe mercantil urbana, a favor da produçâo de mercadorias, contra esta e dentro desta, o qual foi ao mesmo tempo extensảo do modo feudal e condiçáo para sua dissolução. Em cada caso particular representantes de qualquer uma dessas classes poderiam lutar para estender a produçáo e troca de mercadorias, ou para resistir a que estas se espalhassem. Dentro das relaçóes de produção de mercadoria reinan. tes, tais lutas incidiam sobre as condiçốes de exploração e sobre a apropriação do excedente. Os interesses da burguesia urbana, consistentes com sua posiçăo $\mathrm{cm}$. basada no modo de produçáo feudal, convergiam com os da nobreza face ao campo " enquanto a renda permaneceu, em suas várias formas, o principal modo de apro. priação do excedente e o capital permaneceu externo ao processo produtivo " (15). A luta da burgucsia urbana contra a aristocracia não visava mais do que apropriar uma parte maior do excedente e estender o privilégio dentro da ordem feudal. A expansão da produção e troca de mercadorias e o controle monopolista sobre estas podiam dar lugar a conflitos entre a burguesia e a classe aristocrática dos proprietários de terras, da qual o capital mercantil era $\mathrm{em}$ última instância dependente, tanto para sua existência como para manter sob controle - económico, político e militar - os produtores diretos. A aristocracia, por sua parte, podia resistir a imposição das relaçốes da mercadoria em geral, ou às condiçōes particulares de sua extensão para o campo e para o monopólio urbano. Contudo, a medida que a produção para mercado expandia-se e que os tributos feudais eram transformados em renclas monetárias, também a aristocracia tornou-se cada vez mais dependente da troca de mercadorias e da classe mercantil para manter sua posição na sociedade. Apesar da importância crescente das relaçồes da mercadoria no feudalismo curopeu. a persistência da propriedade aristocrática bloqueava a capitalizaçăo da produçăo (16). Assim, as relaçôes entre as duas grandes classes nảo-produtoras da Europa feudal eram condicionadas por mútuo antagonismo e dependência; ao mesmo tempo, ambas lutavam com os produtores diretos para estabelecer a forma e a extensão da apropriação do excedente. Fstes conflitos se desdobraram com a varie. dade de alianças e antagonismos de classe possível em circunstâncias concretas.

$O$ resultado histórico desse conflito foi a dissolução da coincidencia entre as relaçóes políticas e cconómicas de subordinação/apropriação que caracterizava o feudalismo, e a reconstituição de tais relações com base na produçấo de mercado. rias, no capital mercantil e no estado absolutista. A separação formal entre política e economia, característica do capitalismo desenvolvido, começou a emergir de forma rudimentar. A constelação de relaçôes de classe que caracterizava a ordem feudal foi sendo cada vez mais mediada pela forma-mercadoria. O crescimento da produçăo e troca de mercadorias resultou na centralização no nível do estado de relaçốes de poder que antes eram difusas. Como argumenta Anderson:

- Essencialmente, 0 absolutismo era apenas isto: uma aparelbagem de dominaçao feudal reorganizada e reforçada, estrategicamente projetada para fixar as massas camponesas em sua posição social tradicional - apesar do progresso que estas haviam obtido com a generalizada comutação de tributos e em oposição a tais avanços (...) $\Lambda$ forma de poder da nobreza, por sua vez, era determinada pela difusão da produção e troca de merca. dorias nas formaçốes sociais de transição no início da época moderna "(17).

Se o caráter do estado absolutista garantia o poder de classe da aristocracia, como sugere Anderson, a base da dominação aristocrática foi não obstante transformada com a consolidação da propriedade privada e o crescimento das relaçóes da mercadoria(18). Com a emergência do estado absolutista, aprofundou-se a complexa interdependência entre capital mercantil e dominação de classe da aristocracia. $O$ estado absolutista precisava da burguesia urbana para manter sua dominação cen. tralizada, e a classe mercantil assumiu um papel mais decisivo nos negócios de estado. A classe mercantil urbana era necessária para fornecer renclas, para administrar a burocracia do estado, e para desenvolver o comércio, a agricultura e a indústria; por outro lado, a afirmaçáo do poder estatal nos planos nacional $e$ inter. nacional dependia de todos esses processos. Na estrutura do estado propriamente dito forjaram-se novas distinçóes, principalmente através da intervençâo da burguesia, entre a bolsa particular do rei e o orçamento público, entre suas terras privadas c as terras públicas, que dissolviam a coincidência entre poder público e poder

15 Idem, ibidem, p. 180.

16 Vor Anderson, Lineages, p. 17.

17 Idem, ibidem, pp. 18-9. 
pessoal na monarquia feudal, permitindo a concentraçáo do poder político na nova forma de organização estatal. Na outra face da moeda, o estado absolutista foi condị̧ão para a expansão ulterior do capital mercantil e permitiu a plena extensão de monopólios e privilégios, condiçōes, uns e outros, da produção e troca de mercadorias. Estes foram os fundamentos para a formaçăo do mercado mundial no século XVI.

\section{II - CIDADE E CAMPO, ESTADOECOLONIA}

A criação do mercado mundial e da divisão internacional do trabalho através da expansão colonial e da imposição de novas formas de produção e troca de mercadorias permitiu ao capital mercantil desenvolvido superar a contradição entre campo e cidade do modo de produçâo feudal. Incapazes de expandir plenamente as relaçốes de mercado no campo europeu, as classes mercantis urbanas nas cidades portuárias do Atlântico juntamente com os novos estados absolutistas criaram nas colOnias uma hinterlândia rural subordinada através de força e coerçâo, que thes permitiu ultrapassar os velhos centros comerciais da Europa(19). Na ausência de um grande excedente populacional e de uma força móvel de trabalhadores separados dos meios de produção e subsistência, as potências comerciais da Europa podiam aumentar o excedente disponivel para comércio através da concentraçäo forçada de trabalhadores nas colônias, compelindo-os a produzir mais e mais para exportação. na moldura maior das relaçóes pré-capitalistas de produção existentes e da dominação da economia mundial pelo capital mercantil independente. Desse modo, a expansão colonial forneceu ao capital mercantil um caminho para o desenvolvimento da produção de mercadorias e para a socialização do trabalho numa medida que seria impossível na Europa. A exploração das colônias foi essencial para a expansão do comércio e forneceu um meio para acumular riqueza a despeito das relaçôes pré-capitalistas de produção reinantes na Europa.

$\Lambda$ criação do mercado mundial e da divisão internacional do trabalho neste es. tágio histórico foi o resultado da extensão espacial do arcabouço monopolista que definia a cidade frente ao campo dentro do modo feudal(20). Todo um edifício de monopollios, restriçóes e privilégios foi construido, subordinando a produção e o comércio coloniais aos interesses da metrópole e assegurando al classe mercantil a posiçấo favorecida de intermediário na empresa colonial. Contudo, o alcance desses empreendimentos excedia o quadro meramente municipal, e esta expansão do capital mercantil se deu sob a égide do estado nacional. Na falta de mecanismos económicos desenvolvidos, o capital mercantil teve de confiar no poder coercitivo do estado absolutista para criar e manter uma hinterlândia colonial subordinada e assegurar os monopólios de comércio e produção que garantiam à classe mercantil dominar as colônias e o mercado colonial. Os estados nacionais emergentes da Europa mostravam-se ávidos por encorajar a prosperidade comercial e industrial que cra a base de seu poder, tanto na arena nacional como na internacional, nesta época de crescimento da produção de mercadorias. Desempenharam um papel essencial neste momento, excluindo outros paises de operar $\mathrm{em}$ suas colónias e mobilizando recursos escassos para a expansão colonial(21). Assim, o mercado mundial neste estágio estruturava-se através de rivalidades imperiais entre os estados absolutistas, os quais competiam e tentavam monopolizar mercados restritos(22).

Apesar do aumento na produção para mercado c do comércio florescente, o mercado mundial e a divisáo internacional de trabalho que se desenvolveram a partir do século XVI são ainda pressupostos da produção capitalista e não são idên. ticos a divisão internacional de trabalho e ao mercado mundial capitalistas. $O$ capital mercantil curopeu criou o comércio mundial e um mercado mundial ao estabelecer novos pontos de produção e troca, que foram condiçăo para o desenvolvimento pleno da relação capital-trabalho assala riado(23) . Apesar de o capital, enquanto capital mercantil, ainda nảo dominar diretamente o processo produtivo, seu mercado mundial mantém-se como uma unidade face aos diversos produtores sociais e formas de produçâo social, os quais são postos cm relação uns com os outros à medida que a forma-mercadoria é imposta aos produtos do trabalho. A classe mercantil organizou a produçâo em maior escala para incrementar seu monopólio do comércio. $\Lambda$ produção para o mercado mundial criou nova riqueza, aumentou o volume de mercadorias em circulação e tornou possivel a centralização do comércio e a concentração da riqueza. As várias formas de proclução social abarcadas pelo mercado

23 Karl Marx, Theories of Surplus Va tue, IIt, London, 1972, p. 253. 


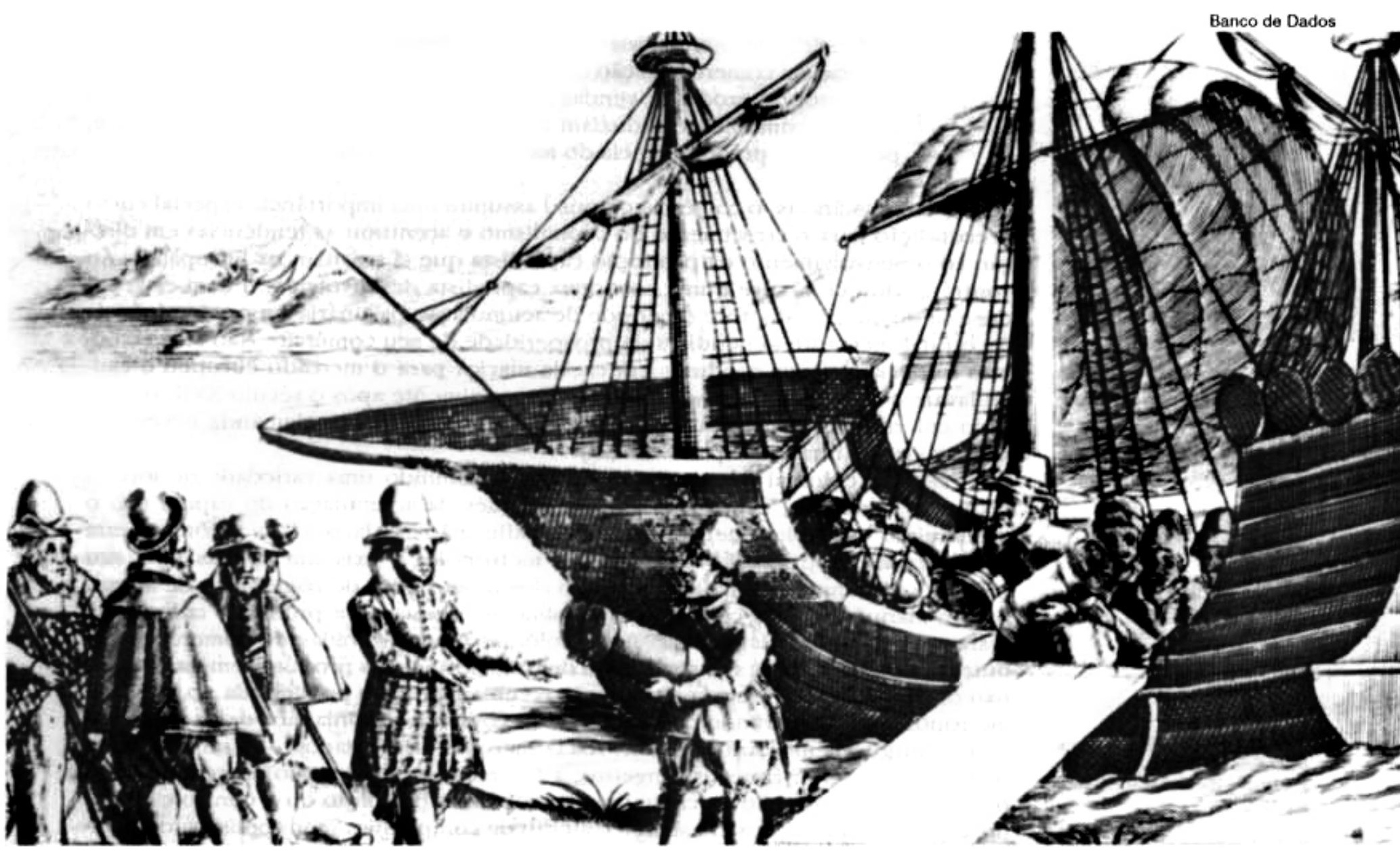

mundial forneceram novos meios de produção e subsistência e criaram condições materiais para a produção e reprodução capitalistas. Por isso o impulso em direção ao monopólio comercial nega-se a si mesmo. Contudo, o mercado mundial durante o período de acumulação originária continuou estruturado pelo capital mercantil independente, que expressa o caráter da cconomia mundial como um todo e configura as relaçôes dentro desta. Sob o capital mercantil, o mercado mundial estabelece dependências recíprocas não pelo movimento dos preços, mas através da coerção. Apesar de mais extenso e diversificado que os mercados anteriores, o mercado mundial continuava a ser uma "presa restrita e sua 'captura' acarretava a imposição de monopólios de produção e troca contra o (novo) campo (colonial) e contra a intromissão de cidades (e estados) rivais, enquanto o comércio continuasse a existir somente nos intersticios do sistema, monopolizando o fornecimento de uma série limitada de bens, e continuasse dependente de indulgências políticas " (24).

Neste passo, o mercado mundial e a divisâo internacional do trabalho foram condição para a separação entre os produtores diretos e os meios de produção, mas este processo estava desenvolvido apénas de modo incompleto, e só excepcionalmente a produção era organizada de modo capitalista. As relaçóes sociais do campo europeu continuavam a limitar tanto a transformação $\mathrm{em}$ mercadoria do produto excedente quanto o desenvolvimento do mercado. A agricultura predominava de maneira esmagadora e, exceto na Inglaterra, onde a produção de mercadorias, a oposiçâo entre cidade e campo e a agricultura capitalista mais haviam progredido, a maioria do que a população rural européia consumia era produzido localmente. Merrington descreve a ausência de uma economia de mercadoria desenvolvida durante este periodo:

"Nāo devemos perder de vista esse caráter feudal do 'capitalismo' inicial; a circulação baseada na livre troca de equivalentes pertence ao desenvolvimento pleno do mercado capitalista. Mesmo no século XVIII, na maior parte da Europa o mercado mantinha-se limitado a uma determi-
Os holandeses, comerciantes e carregadores de mercadorias de outros povos, ergueram o primeiro império comercial global 
25 ldem, ibidem, pp. 180-1. Ver tam bem: Eric J. Hobsbawm, Industry and Empire, Harmondsworth, 1969. pp. 40-1.

26 Marx, Grundrisse, pp. 508-11.

27 Ver Eric J. Hobsbawm, "The Crisis of the Seventeenth Century ${ }^{\prime \prime}$. in Trovor Aston, ed., Crisis in Europe, 1560-1680, Garden City. Now York, 1967, pp. 53-6.

280 comercio aparece aquil como combrcio de extremos. "Quanto mais as colónias diferem da metro polo, mais sho perfeitas, como no caso das Antilhas". escreveu Louis XN ao governador da Mat tinica em 1670, (Citado em Jose León Suárez. Carácter de ta Re volución Americana, Buenos Aires. 1917. p. 7 .

29 Ver Nukolai Bukharin, Imperialism and Worid Economy, New York. 1973. pp. $25-6$

30 Marx, Grundrisse, p. 529n; o tarn bem Capital, I, p. 443

31 A medida que o capital mercant organizava o trabalho ativo na for. ma de trabalho escravo no Novo Mundo, estabelecia na África a categoria de trabalho de reserva Mais do que urna "arena exter na", a Arica integrava as rela poes de produçáo que se iam es tabolecendo. Net Immanuel Wal lerstein, The Capitalist World Eco nomy. Cambridge. 1979 Pp. 215-7.) O trabalho africano tornou-se reserva latente de tra baliho de facto, jî que em relagelo ao trabalho escravo do Novo Mun. do mantinha -se corno tonte poten cial de máo-de-obra. nada série de mercadorias, os salírios cram f́reqüentemente pagos em espécie e a comercializaçâo da agricultura cra apenas parcial. O consumo pelo próprio produtor, vendas através de simples troca, e pagamentos em especie comumente reduziam a extensảo das transaçōes monetárias e, portanto, a predominância do mercado " (25).

Nestas circunstâncias, o comércio colonial assumiu uma importância especial como precondição para o crescimento do capitalismo $\mathbf{c}$ acentuou as tendências $\mathrm{em}$ direçăo ao desenvolvimento da produção capitalista que já existiam na Europa(26). Ao contrário do que ocorre numa economia capitalista desenvolvida, o bem-estar industrial de um país durante o periodo de acumulação originária e a predominância do capital mercantil dependiam da prosperidade de seu comércio. Nâo só as colônias forneciam novos produtos em escala maciça para o mercado europeu e estimulavam o comércio e a navegação mas, especialmente apos o século XVII, o mercado colonial desempenhou um papel crucial, ao oferecer a demanda necessária para as manufaturas se expandirem(27).

O sistema colonial que emergiu, mesmo assumindo uma variedade de formas históricas concretas, expressava as necessidades da acumulação do capital sob o predomínio do capital mercantil e do trabalho nâo-assalariado. As colónias eram consideradas propriedade exclusiva das metrópoles e existiam apenas para seu proveito. O campo colonial era excluído dos monopólios de comércio e de artesanato e manufatura nas cidades metropolitanas, enquanto a produção colonial se restringia a produtos agrícolas(28). As colónias cram proibidas de comerciar com outros paises que não a metrópole, ou de transportar seus produtos em navios que não os da metrópole, e em compensação recebiam posiçăo privilegiada no mercado metropolitano. Reservando os beneficios do comércio colonial aos da nação - ou seja, a burguesia mercantil dos centros comerciais privilegiados - o sistema colonial visava a excluir rivais estrangeiros, a favorecer o crescimento do comércio e a promover a acumulação de capital na metrópole. $\Lambda$ proibição ou o controle de im. portaçồes e exportaçöes, o estabelecimento de companhias monopolistas, os privilégios concedidos a empresas privadas, o regime do "exclusivo" metropolitano e leis como as Navigation Acts convergiram para mobilizar os recursos, em expansão mas limitados ainda, de vários estados europeus e de scus centros de comércio marítimo a fim de utilizá-los para a exploraçấo das colônias, para assegurar novos mercados e fontes de matérias-primas protegidos da competiçăo estrangeira, e para estimular indústrias $\mathrm{e}$ artesanatos nos centros metropolitanos.

A escravidảo colonial no Novo Mundo surgiu e desenvolveu-se como uma forma particular da produção de mercadorias, inseparável do mercado mundial e da divi. sấo internacional do trabalho criados pela expansão do capital mercantil curopeu a partir do século XVI. As relaçôes escravistas não sâo separadas do mercado mundial ou anteriores a este. Antes, formam uma parte constitutiva da divisão internacional do trabalho - a totalidade das relaçốes sociais de produção e troca constituindo o mercado mundial(29). A produção escravista nas Américas baseava-se na divisão in. ternacional do trabalho e no mercado mundial e deriva sua especificidade face a outros sistemas escravocratas de sua relaçấo com a totalidade das relaçôes do capital em desenvolvimento. Ao mesmo tempo, as relaçôes escravistas impuseram suas pró. prias condiçóes na produção e reproduçấo social e determinaram a especificidade da escravidấo frente às outras formas de produção de mercadorias na economia munclial. Assim, a racionalidade e o caráter específico das formaçōes escravistas no Novo Mundo estabeleceram-se através da relaçâo simultânea entre a cconomia mundial do capital em desenvolvimento, de um laclo, $\mathbf{c}$ a relação senhor-escravo, do outro. A produção escravista foi responsável pelo expandir e elaborar da divisão internacional do trabalho e pela ampliậa do mercado mundial; mas este sistema de produção social cra também relativamente estático e inflexível, possuindo uma capacidade limitada para interagir com a transformação capitalista da cconomia mundial que cle mesmo contribuia para levar a efeito.

$\Lambda$ razấo de ser da cscravidão colonial era a produçấo de mercadorias. $\Lambda$ produção de um excedente para comércio foi expandida violentamente. Ao estabelecer rela. çós escravistas no Novo Mundo, o capital mercantil criou uma nova força proxlutiva: à medida que os esforços dos escravos eram reunidos e combinados, a força de trabalho cooperativa tomava corpo(30). A África converteu-se numa reserva de tra. balho barato(31), e massas de africanos foram escravizadas, Iransportadas para o 
outro lado do Atlântico, concentradas em plantattons nas Américas, e compelidas a gastar sua energia - dia após dia, mês após mês, ano após ano - na produção de gêneros básicos (açúcar, café, tabaco, algodão) para exportação à Europa. Nas colônias escravistas, a força social do trabalho coletivo foi desenvolvida num grau muito mais alto do que o possível na metrópole. $\Lambda$ cooperação dos trabalhadores foi organizada numa dimensão mais ampla, e houve maior concentração e centralização de produção nas grandes fazendas escravistas(32)

O desenvolvimento da força produtiva de massa do trabalho escravo teve por premissa a relação da escravidão com o todo da economia mundial. Capital e escravos puderam ser acumulados em plantations nas Américas para a produção irrestrita de gêneros para exportação apenas porque, através da divisão de trabalho no mercado mundial, as colónias escravistas recebiam produtos finais, carne salgada, madeira de construção, gado, escravos, e bens manufaturados que de outra maneira teriam de produzir por conta propria. O crescimento da produção escravista era dependente do desenvolvimento qualitativo e quantitativo da economia mundial como um todo (a capacidade de o capital mercantil financiar e manter novas $\mathrm{cm}$ presas coloniais, fornecer mercados para a produçāo colonial, etc.). Através dessa divisâo internacional do trabalho, a produçāo escravista acelerou tanto o desenvolvimento da força coletiva do trabalho cooperativo quanto a elaboração da divisão social do trabalho, nấo só no nível das formaçôes escravistas, mas também no nível da economia mundial como um todo(33).

O senhor de escravos realizava seu excedente como lucro no mercado atraves da mediação do capital mercantil e tinha de corresponder à demanda e levar em conta os padrōes do mercado para ser bem-sucedido. Contudo, a escravidão propriamente dita baseava-se na coerção física direta do trabalhador, não no trabalho formalmente livre. A organização interna do processo de trabalho não era diretamente sujeita à dominaçâo do capital, mas, ao contrário, era moldada pela relação senhor-escravo. Na economia escravista a força de trabalho não é separada da pessoa do trabalhador. Ao contrário do capitalista, que paga um salário pelo uso da força de trabalho, o senhor de escravos possui o trabalhador. Este não mantém relação alguma com os meios de produção, mas é ele mesmo um instrumento de produção, como um boi ou um jumento. O escravo representa um investimento de capital que náo é diferente daquele feito $\mathrm{cm}$ máquinas ou gaclo. O preço do escravo bascia-se $\mathrm{cm}$ sua capacidade de produzir, mas este capital é independente do capital empregado para explorá-lo no processo de produção propriamente dito(34).

$\Lambda$ produção de excedente é o elemento fundamental da economia escravista, mas tanto o valor da força de trabalho como a distinção entre trabalho necessário c trabalho excedente estâo ocultos pela relaçâo de propriedade na sociedade escravista. Uma vez que na cconomia escravista a força de trabalho não é mercadoria, não há um valor para a força de trabalho que possa se distinguir do valor do trabalhador. O escravo propriamente dito é uma mercadoria, mas as relações de mercadoria não estruturam o processo de trabalho escravo. Não há na cconomia escravista um equivalente para a forma salário. A produção escravista não se apóia na " livre troca de valores equivalentes ", como os contratos no regime de trabalho assalariado, mas na dominação direta e explicita do escravo. Na relação salarial, a produção c apropriação do valor excedente é mascarada pela aparente troca de equivalentes entre capital e trabalho. Sob a escravidão, a relação entre trabalho necessário e trabalho excedente é oculta pela ausência de uma tal troca. O trabalho escravo é diretamente apropriado pelo senhor. Mais aincla, já que o fazendeiro tem de arcar com o custo de reprodução do escravo, todo trabalho deste lhe aparece como trabalho excedente não-pago. 'Tudo o que o escravo produz é propricdade do senhor (35). O dispêndio da força de trabalho, a atividade de trabalhar, não é parte do custo da produção na economia escravista. Ao invés clisso, o custo do traballo aparece como uma série de investimentos $\mathrm{em}$ capital constante (construçōes, comida, roupas, etc.). Os valores produzidos pelo escravo não representam a força de trabalho na produção. mas antes a renovaçâo de uma quantia de capital constante, e sấo cquivalentes ao custo de manutenção, combustível, etc., para máquinas. Mesmo a parte do trabalho do escravo que reproduz seus meios de subsistência corresponde à reprodução do capital investido nele.

A ausência da força de trabalho como um custo de produção separado e sua assimilação à quantia de capital constante estāo na raiz daquilo que Weber e outros que o seguiram apontam como a "irracionalidade" da cconomia escravista. Douglas
32 Vot Marx, Capital, 1, p. 925, nota 12

33 Ver Marx, Grundrisse, p. 586.

34 Vor Marx, Capital, III, p. 809, e tamberm Capital, III, p. 483

35 Marx, Capital, I, p. 591. Ver tambern: Herbert C. Gutman, The BlackFamilyinSlaveryandFreedom: 1750-1925, New York, 1974, e George P. Rawick, From Sundown to Sunup: Tho Making of the Black Community, Westport, Conn., 1972. 
Hall, historiador da Jamaica, enfatizou as dificuldades causadas por esta forma de organização do trabalho para a racionalização da proxlução nas economias escravistas das Antilhas:

"Que os escravos das fazendas cram uma forma de investimento em ca. pital constante não há dúvida. Conseqüentemente, seu 'trabalho' não era' trabalho' no sentido em que usamos esta palavra com respeito a 'trabalhadores livres' ; porém, mais precisamente, 'força', no sentido em que esta palavra é usada para designar os esforços do gado ou o funcionar da maquinaria (...) Portanto, a aboliçáo da escravatura afetou a indústria não porque substituiu 'trabalho escravo' por 'trabalho assalariado', mas porque introduziu o 'trabalho' como um componente significativo da produção e da contabilidade (...) e porque trouxe importância e significado real a conceitos como 'custo do trabalho', 'produtividade do trabalho', e 'poupança de trabalho' pela primeira vez nas Antilhas "(36).

A ausência da força de trabalho como mercadoria na cconomia escravista mostrou-se uma barreira quase intransponivel para a racionalizaçăo da produção. No escravismo náo havia um equivalente para o salário que fornecesse um mecanismo para a variaçâo da força de trabalho de acordo com as condiçôes do mercado c, mais im. portante, que fornecesse um meio de baratear constantemente o custo da repro. dução da força de trabalho.

A falta de distinçáo entre capital constante c capital variável e o não aparecimento do trabalho $\mathrm{em}$ ação deram um caráter estático ao sistema de produção escravista. $\Lambda$ relação entre trabalho necessário e trabalho excedente permaneceu relativamente estável na economia escravista. O senhor de escravos nảo possuía sob seu controle direto nenhum meio para reduzir o tempo de trabalho necessírio, que já estava reduzido ao mínimo. No curso da história as necessidades de subsisténcia dos escravos foram quase invariáveis, e o tempo em que os escravos produziam para sua própria subsistência permaneceu relativamente inalterável. Se as condiçôes do mercado fossem favoráveis, o senhor poderia, em princípio (apesar de não ser tâo fácil na prática), deslocar escravos da produção para subsistência para a produção de gêneros de exportação. Contudo, em qualquer dos dois casos o trabalho necessário era realizado no tempo de senhor; $\mathrm{e}$, se o fazendeiro fizesse uma tal mudança, teria de suprir de seu próprio bolso, através de compras, as necessidades de subsistência dos escravos. A parte do consumo dos escravos que o senhor supria por meio de compras no mercado correspondia a compras de quantias fixas de bens, e representava uma quantia relativamente inflexivel de trabalho necessário. $O$ valor destes bens poderia ser barateado através de mudanças na produçấo $\mathrm{em}$ algum outro ponto de economia mundial. Com o trabalho necessário nas plantattons já reduzido ao minimo. somente o surgimento da produção através de trabalho assalariado no Velho Mundo poderia reduzir significativamente os custos de certos produtos de que os escravos precisavam para subsistir. Contudo, os preços destes bens eram determinados fora da esfera da produçáo escravista, para além do controle da classe dos senhores de escravos. Mais ainda, a capacidade de o senhor se valer de bens de preços mais baixos era dependente de sua capacidade de efetuar o controle monopolista da classe mercantil.

As relaçôes escravistas inibiram a introdução de inovaçôes tecnológicas que au. mentassem a taxa de produção do excedente. Não só o capital investido em escravos limitava a compra de máquinas, fertilizantes, etc., mas o senhor não podia ajustar sua mão-de-obra às mudanças tecnológicas com facilidade. Ou bem suas máquinas ou bem seus homens ficavam mal aproveitados. Além clisso, a menos que o trabalho necessírio fosse reduzido, aumentar o excedente poderia abaixar o preço do produto sem reduzir os custos para o senhor dos escravos. Assim, a forma particular das relaçốes escravistas implica em que a expansão do sistema escravista tenha sido antes extensiva que intensiva. $O$ uso da força muscular humana perma. neceu no centro do processo de trabalho e a produçāo de excedente foi aumentada através da concentraçâo de mais trabalho $\mathrm{cm}$ mais terra por periodos maiores de tempo. I ma vez que fossem alcançados os limites da produção de excedente absoluto, aumentar o volume $\mathrm{e}$ a intensidade do trabalho excedente cra fator bem mais decisivo na produçấo escravista do que aumentos relativos na taxa de procluçấo de excedente. Para o desenvolvimento da escravidăo colon:ial a extensão quantitativa 
era mais importante do que a transformação qualitativa, como indica o historiador cubano Manuel Moreno Fraginals:

"'Trata-se de uma mudança quantitativa, em uma atividade manufatureira agrícola, cm que a mão-de-obra relativamente numerosa revoluciona as condiçôes objetivas do processo de trabalho, embora o sistema em si não mude. $\Lambda$ forma deste é a de um mecanismo de produção cujos componentes são os homens. As operaçôes retêm seu caráter manual, dependendo da força, da destreza, da velocidade e da segurança do trabalhador individual no manejo da ferramenta. Desse modo, o que é característico da transformaçăo que encontramos em Cuba com o crescimento desmesurado de tal cooperação é que este aumento tem um caráter quantitativo. O crescimento ocorre por meio do uso de mais terras para cana, de mais corte de lenha, mais caldeiras, mais fôrmas, mais carroças, mais gado; mas isto tudo sem alterar os padrồes anteriores, a não ser para submeter o negro a um modo de vida cada vez mais bestial, reduzindo seus anos úteis a limites inacreditáveis. É a criação de um mundo novo, que soma à barbárie da escravidão os tormentos civilizados do trabalho excedente. Este método característico de expandir a produçâo açucareira, por sua vez. tem repercussôes em toda a esfera colonial $\mathrm{e}$, à medida que se desenvolve, absorve uma grande parte da energia antes dirigida a outras atividades" (37).

Por conseguinte, a distribuição do tempo de trabalho durante o dia, a semana ou o ano era sujeita a limites naturais, fisicos e sociais, e havia pouca oportunidade para ampliar o tempo de trabalho excedente. A expansão da produção escravista poderia ocorrer somente através da incorporação de novas terras e de um suprimento contínuo de mão-de-obra para as áreas novas. Esta forma relativamente estável de trabalho excedente oferecia lucros satisfatórios enquanto os monopólios mercantis mantiveram altos os preços. Mas quando a competiçâo no mercado levou à diminuição de tais rendimentos, a organização bascada no trabalho escravo passou a fornecer poucos meios para que o fazendeiro aumentasse o excedente a seu dispor. A expansão da escravidão cria condições para seu próprio declínio.

\section{III - E S C RAVIDÄO E TRABALHO E S RAVO NO D ESENVOLVIM E N TOH I T ÓR I C O DA E C O N O M I M U N D I A L C P I TAIISTA}

A escravidão colonial no Novo Mundo integrava os processos de acumulação originária do capital. As relações escravistas de produção foram uma cpndição bistoricamente necessária para a emergência do trabalho assalariado como a forma dominante da produção social e assim fazem parte da totalidade concreta da produçäo capitalista. Por conseguinte, o trabalho escravo na cconomia mundial deve ser apreendido $\mathrm{em}$ sua relação $\mathrm{com}$ o trabalho assalariado, do qual é pressuposto histórico. Nem a escravidão nem o trabalho assalariado podem ser isolados, como modos de produção distintos, de seus contextos históricos. Um e outro se desenvolveram reciprocamente. Apesar de o trabalho assalariado ser decisivo para as relaçôes de produção capitalistas, o capital não organiza o trabalho exclusivamente como trabalho assalariado; antes, éxerce sua dominaçāo através de uma variedade de formas, assalariadas ou não. O capital deve ser entendido, portanto, como a relaçâo entre essas formas: neste caso, como a relaçīo entre trabalho escravo e trabalho assalariado.

Concretamente, a produção capitalista foi organizada em escala mundial, estabelecendo-se uma hierarquia global do trabalho que compreendia várias formas de produção social. Na Europa ficava o ponto focal dessa rede munclial de proclução c troca de mercadorias. $\Lambda$ ampla organização da produçāo de mercadorias através do trabalho nảo-assalariado $\mathrm{cm}$ outras partes do globo permitiu a concentração na Europa de atividades econômicas que, por sua vez, foram condiçâo para o desenvolvimento neste continente do trabalho assalariado. A transiçâo para o capitalismo acarreta, portanto, a transformação qualitativa da cconomia mundial: de processos e relaçōes que produzem a relação capital-trabalho assalariado para a cconomia mundial capitalista, que é constituída $\mathrm{e}$ reproduzida, $\mathrm{cm}$ escala que se cxpande cada

37 Manuel Moreno Fraginals, EI In genio, I, La Habana, 1978, p. 48 
vez mais, através do movimento da relạ̧ão capital-trabalho assalariado propriamente dita. Assim, a transiçāo para o capitalismo e o desenvolvimento deste envolvem a recomposiçâo do trabalho - das várias formas do trabalho internacionalmente organizadas. Nesse processo descontínuo e não-linear está implícito um movimento da escravidão como a relaçăo que produz a relação capital-trabalho assalariado para a escravidão como produto desta relação. (O significado sistêmico da escravidão e transformado uma vez que a relação capital-trabalho assalariado é amplamente estabelecida. Na primeira situaçăo, a escravicláo e um meio de incre. mentar o monopblio do comércio pela classe mercantil. Ao fazer isso, esta classe corre o risco de se arruinar ao produzir mercaclorias "demais ", isto c, de modo a causar a queda de preços. Na segunda situaçâo, a escravìão é importante como um meio de reduzir o custo do capital variável empregado na reproduçấo da classe de trabalhadores assalariados.)

A escravidão colonial nas Américas deu ímpeto à produção de mercadorias e contribuiu para o desenvolvimento da cooperaçáo, da divisâo do traballo, da con. centração dos meios de produção $\mathrm{c}$ do desenvolvimento das forças produtivas na cconomia mundial durante o período de acumulaçáo originária. Auxiliou, assim, a estabelecer um volume e uma complexidade de atividades que foram condição para o desenvolvimento das relaçóes de produção capitalistas(38). A escravidão foi de fundamental importância para o sistema colonial e para o sistema de créclito público descritos por Marx como as "poderosas alavancas da acumulặ̃o " durante este periodo(39) . A escravidão promoveu o crescimento c a centralização de mercados, a concentrạ̧ão da riqueza monetária, a criạ̧ăo de novas necessidades c a expansão das antigas num grau que só poderia ser satisfeito através da expansão da base produtiva para a acumulação de capital na Europa.

A escravidão c o sistema colonial foram incentivos importantes para o desenvol. vimento do trabalho assalariado e da manufatura na Europa. As condiçốes de produção e consumo foram sendo cada vez mais mediadas pela troca, e a riqueza monetária gerada através do colonialismo, da escravidão e da expansão do comércio foi concentrada nas mãos das classes apropriacloras e contribuiu para separar os produtores europeus dos meios de produçăo e subsistência(40). Bolsôes isolados de trabalho assalariado permaneciam engastados nas relaçôes sociais da Europa, reproduzidos dentro de relaçōes sociais distintas da relação capital-trabalho assalariado e através destas. Mas estes centros de manufatura eram incapazes, por si sós, de transformar as relaçóes sociais na Europa, e seu crescimento e desenvolvimento foram diretamente proporcionais à expansão do mercado mundial c a divisão internacional do trabalho(41). O sistema escravista nas Américas e o correspondente comércio de escravos forneceram um mercado de importância decisiva para os bens manufaturados europeus. A produção capitalista para mercado começou a se desenvolver $\mathrm{cm}$ ritmo crescente na Europa $\mathrm{c}$ novos centros manufatureiros se estabele. ceram, primeiramente no campo, fora dos velhos centros de controle e restriçăo municipal c, mais tarde, também nos centros urbanos. Ao mesmo tempo, os produtos coloniais contribuíram diretamente para a diminuị̂ấo dos custos de repro. dução da força de trabalho dos assalariados. Gradualmente, com o surgimento da relação capital-trabalho assalariado, começou a emergir um imperativo sistêmico para transformar a produçāo, tanto através da inovação tecnológica quanto por meio da reduçáo contínua dos custos da força de trabalho.

De um ponto de vista histórico, os processos da acumulạ̣ão originária desen. volverám-se, no nivel da economia mundial, através de rivalidades e da dominação sucessiva de Portugal, Espanha, Holanda, França e Inglaterra, com scus respectivos impérios coloniais. Estes processos foram condição para o desenvolvimento da produção capitalista. Fó expandida a base produtiva c comercial da economia mundial e da divisăo internacional do trabalho; entretanto, a organização destas últimas era ainda estruturada pelo capital mercantil e cxpressava os limites deste. A expansấo das atividades produtivas dependia do exercício direto da força, nâo só no caso das formas de trabalho compulsorio nas colónias, mas também na Europa, onde os produtores eram expropriados por meio de violéncia e o proprio trabalho assalariado ainda não havia adquirido seu caráter " formalmente livre" (42). A econo. mia mundial como um todo sofreu os ciclos de expansão c involução (por exemplo, a "crise do século XVII") que caracterizam a acumulậ̣o bascada no capital mercantil.

A produçấo capitalista emergiu primeiro na Inglaterra, pais cm cujos limites na- 
cionais mais estavam desenvolvidas a produção e troca de mercadorias e que havia assegurado posição predominante na economia mundial. Entretanto, a criaçăo de uma classe de trabalhadores assalariados livres $e$ a subordinaçâo do trabalho assalariado ao capital não são nem produtos da extensão linear das forças de mercado, nem multiplicação ou expansão quantitativa dos bolsōes de trabalho assalariado previamente existentes. Antes, a predominância da forma assalariada de trabalho representa uma ruptura com o modo de organizaçáo social anterior e uma transformação qualitativa da totalidade das relaçôes sociais do capital e das condiçôes sociais da produçấo material. Assim que a forma assalariada do trabalho se torna dominante, destrói as condiçôes através das quais veio a existir e cria condiçōes para sua expansão ulterior. Nảo se pode mais propriamente falar $\mathrm{em}$ acumulação originária do capital, mas antes $\mathrm{cm}$ reproduçẩo ampliada do capital e acumulação capitalista(43).

Quando o trabalho toma a forma da mercadoria " força de trabalho", todos os elementos entram no processo de produção capitalista como mercadorias e todo o produto toma a forma de mercadoria. São removidas todas as barreiras sociais previamente existentes contra a produção de excedente. A forma complexa e desenvolvida da mercadoria emerge como a unidade de valor de uso e valor de troca, e a produção é constituida de acordo com uma lei de valor. A produção social é organizada como produçáo e reproduçâo de valor e é continuamente transformada por meio da valorizaçäo do capital. Através da forma assalariada de trabalho o capital pode tomar controle direto do processo de trabalho e estabelecer a subsunção real, não-formal, do trabalho ao capital. Com a produção por meio de máquinas, os instrumentos de trabalho, e não seus agentes humanos, tornam-se o centro do processo de trabalho. O capital pode afirmar sua dominação sobre o tempo de trabalho disponivel dos trabalhadores de modo muito mais completo do que o possível na manufatura, e pode também desenvolver esse tempo como tempo excedente, tanto absoluta quanto relativamente, através da transformaçāo técnico-organizacional do processo de trabalho. $\Lambda$ divisão de trabalho é revolucionada, e todos os ramos da produção são transformados e diversificados. As barreiras contra a mobilidade do trabalho são removidas, a relação do trabalhador com seu trabalho é continuamente alterada, e o trabalho é constantemente recomposto pela necessidade de o capital desenvolvê-lo como capital variável(44). Com o desenvolvimento da moderna indústria de grande escala, o capital cria um modo de produçäo material que the é adequado e aumenta o poder coletivo do trabalho social cooperativo, levando-o muito além do possivel com a divisão de trabalho nas manufaturas ou com o trabalho coletivo de massa das grandes fazendas escravistas. A predominância do capital na economia mundial $e$ assegurada não apenas pelo caráter formal da relaçấo capitaltrabalho assalariado, mas também pelo âmbito e pela escala em que o capital estabelece a produçấo material. $\Lambda$ emergência da produção capitalista na Inglaterra no fim do século XVIII pôs em movimento o processo histórico de transłormação da economia mundial com base na relação capital-trabalho assalariado e na indústria em grande escala.

A produção e a reprodução da relação capital-trabalho assalariado constituem a economia mundial como uma economia especificamente capitalista. Uma vez que o capital assume controle do processo de trabalho, o capital é capaz de criar dentro de seus próprios processos condiçôes para a produção e reprodução, em escala cada vez maior, da relação social entre trabalho assalariado e capital. Os momentos da produção capitalista agora são resultiado do processo de produção capitalista e condição para a produção renovada do capital $\mathrm{cm}$ escala que se amplia. $\Lambda$ mais-valia produzida e apropriada pelo capital deve ser convertida em mais capital, aumentando o poder deste sobre o trabalho. $O$ trabalho, por outro lado, emerge do processo de produção apenas com as condições de sua reprodução como força de trabalho, e com a possibilidade de vender novamente sua capacidade subjetiva para o capital. A relação social entre trabalho assalariado e capital é agora produto da produção capitalista e a acumulaçẩo de capital é a reproduçấo dessa relação social em escala ampliada(45).

\section{IV - O TRA BALHO A S S LARIADO EA DESTRUIÇÃ O D A E S C R A VI D Ã O}

O trabalho assalariado, como forma dominante de trabalho social, fornece o di-

43 Vet Merrington, op. cit. p. 187.

44 Idem, ibidern, p. 190.

45 Marx, Results of the Immediate Process of Production, apêndice, Ca. pital,1, pp. 1061-1062. 
namismo essencial da acumulação capitalista, na medicla em que o capital luta, através da forma-salário, e dentro desta, para impor de modo cada vez mais completo sua dominaçâo sobre o processo de trabalho e para estabelecer as condiçôes de sua reprodução $\mathrm{cm}$ escala ampliada. Entretanto, a predominância da relação capital-trabalho assalariado deve ser considerada $\mathrm{cm}$ relação $\mathrm{com}$ as formas nâo-assalariadas de trabalho social. A acumulação capitalista, encarada como a unidacle contraditória de produção e reprodução, implica e exige não apenas que se criem mais e mais proletários, mas também que todas as formas de trabalho social sejam postas em relaçảo com o trabalho assalariado. A capacidade de a relação capital-trabalho assalariado estabelecer-se como o elo indispensável - aquele cuja produção e reproduçăo constitui c anima a economia mundial - define sua predominância. O trabalho assalariado agora reproduz todas as outras relaçốes da conomia mundial como produtos seus e momentos de sua reprodução. As formas não-assalariadas de trabalho social na economia mundial são agora resultado do capital e são reproduzidas através dele e dentro dele. O trabalho não-assalariado está firmado no mercado capitalista mundial e na divisão internacional do trabalho, os quais the integram a reproduçấo(46). Ao mesmo tempo, as formas não-assalariaclas de trabalho são moldadas de acordo com as necessidades do capital e constituem momentos de sua reproduçấo. Portanto, o processo de produção e reproduçấo das relaçôes sociais do capital cria e guarda em seu bojo a relação entre as várias formas de trabalho social como momentos subordinados, aspectos de um único movimento global de acumu. lação. De um ponto de vista histórico, a relação capital-trabalho assalariado recompốc a cconomia mundial de acordo com suas necessidades e processos, e desse modo pồ $\mathrm{cm}$ andamento uma luta global contra o capital. Defrontamo-nos, assim. com uma relação de classe entre trabalho e capital $\mathrm{cm}$ escala mundial, que assume uma variedade de formas organizadas $\mathrm{em}$ torno da forma-salário. $\mathbf{A}$ totalidade dessas relaçổes sociais constitui as condiçổes concretas de produçâo e reproduçâo capitalistas, as quais devem ser entendidas em termos de: 1) reproclução da relaçâo capital-t rabalho assalariado, 2) reprodução das formas nảo-assalariadas de trabalho e 3) reproduçăo da relação entre as formas de trabalho assalariadas c as não-assalariadas.

A emergencia histórica do trabalho assalariado transforma as relaçōes até então vigentes na cconomia mundial e estabelece o modo de proxlução capitalista como uma totalidade concreta que abarca tanto o trabalho assalariado quanto o não-assalariado numa escala mundial. Como parte da recomposiçấo da economia mundial de acordo com os imperativos da produção através do trabalho assalariado, o mercado mundial propriamente dito é reconstituido e se descnvolve com base na produçâo capitalista, e nâo mais com base no capital mercantil:

" Originalmente, o comércio foi precondiçấo para a transformação das oficinas urbanas, das indústrias domésticas rurais c da agricultura feudal $\mathrm{em}$ empresas capitalistas. O comércio desenvolve o produto tornando-o mercadoria, em parte através da criaçâo do mercado para este, em parte através da introdução de novos equivalentes para a mercadoria e do suprimento de novas matérias-primas e matérias suplementares para a produçâo; criando dessa maneira novos ramos de produçâo, baseados descle o início no comércio, tanto no que diz respeito a produçấo para o mercaclo doméstico e o mercado mundial, quanto no que se refere às condi̧̧ôes de produção originadas no mercado mundial. Assim que a manufatura, particularmente a indústria $\mathrm{cm}$ grancle escala, adquire força suficiente, cria, por sua vez, um mercado para si mesma, capturando-o através de suas mercadorias. Neste ponto, o comércio passa a estar a serviço da produçaio industrial, para a qual se torna necessidade vital a expansāo contínua do mercado. A produçâo em massa, que cada vez mais se amplia, inunda o mercado existente e assim pressiona continuamente para uma expansão ainda maior de tal mercado, para que este rompa seus limites. $O$ que restringe esta produção $\mathrm{cm}$ massa não ć o comércio (na medida em que este expressa uma procura existente), mas a magnitude do capital empregado e o nivel de desenvolvimento da produtividade do trabalho. $O$ capitalista industrial tem sempre à sua frentc o mercado mundial e compara, e muito constantemente compara, scus próprios preços de custo com os preços do mercado doméstico e com os preços $\mathrm{cm}$ todo o mundo. Nos tempos iniciais, uma tal comparạ̧âo cabia quase inteiramente aos

47 Marx, Capital, III, p. 336. Vet tarn. bém: Grundrisso, pp. 407.8 .
46 Ver Marx, Theories of Surplus Va hio, III, p. 243 
comerciantes e assim assegurava o predomínio do capital mercantil sobre o capital industrial" (47).

A circulação e o mercado mundial nẫo são mais precondiçōes externas e históricas da produção capitalista, mas, antes, sua conseqüência, formando um momento subordinado dentro desta(48). A economia mundial capitalista é a unidade específica da produção e da circulação e integra tanto os processos de produção e reprodução das formas de trabalho assalariadas e nāo-assalariadas quanto a totalidade global das relaçốes capital-trabalho.

O sistema de privilégios, restriçốes e monopólios mercantis que havia constituído a economia mundial foi transformado, c a economia mundial reconstituiu-se através dos processos de produção e acumulação capitalista. A predominância do capital nẩo depende mais de disparidades entre preço de custo e preço de venda. Antes, a produção industrial e o mercado mundial integrado nivelam diferenças de preço, e assim se estabelecem preços mundiais. $A$ acumulação capitalista repousa agora no volume da produção e no grau de exploração da força de trabalho, e por esses meios a economia mundial foì transformada no curso da história. Através dos processos de acumulaçăo e reprodução ampliada o capital lutou por expandir e aprofundar seu controle sobre o trabalho, recompondo o trabalho no mundo inteiro, prefigurando e condicionando historicamente a mobilidade universal do trabalho e do capital(49).

Sob as condiçôes da acumulação capitalista, a ciclade não é mais um encrave que impổe sua dominação a partir do exterior. Não só são desenvolvidos, no curso da história, novos centros industriais urbanos, como também a relação cídacle-campo é reproduzida e continuamente transformada, numa escala global, pelo próprio processo de acumulação capitalista. Relaçōes sociais e processos de produção são transformados e distribuídos espacialmente a partir do interior desse processo. Desigualdades regionais se acentuam e a oposição entre cidade e campo é rcconstituída como oposiçẩo entre preços industriais e preços agricolas(50). Do mesmo modo, o caráter e as condiçôes de existência do estado são completamente transformados pelo processo de acumulaçấo capitalista. $\Lambda$ s condiçôes de exterioridade do estado face a processos económicos durante o período de acumulação originária săo inteiramente diferentes das encontradas no período de acumulaçáo capitalista propriamente dita. A concepção marxista ortodoxa do estado como uma superestrutura política montada sobre uma base econômica obscurece este problema. $O$ estado absolutista permanecia fora da produçāo e troca pré-capitalista de mercadorias e fora da acumulação mercantil como condiçâo destas, e simultancamente constituia-lhes os processos. A produção capitalista de mercadorias e a acumulação capitalista, por outro lado, reconstituem o estado como produto da relaçäo capital-trabalho assalariado.

A forma característica da produção e acumulação capitalistas, que distingue estas de outras formas de produçäo social, baseia-se na troca de valores equivalentes e, portanto, implica esferas separadas de produção e de reproduçáo mediadas pela troca. Capitais privados, entretanto, nâo podem garantir nem equivalência nem troca com o trabalho, devido às lutas entre capital e trabalho na produçấo e na reproduçẫo. Por isso, está alem da capacidade de capitais privados reproduzir a relação capital-trabalho assalariado $\mathrm{cm}$ geral. $O$ estado, enquanto capital social, tem de mediar a relação entre produção capitalista e reprodução do capital, e sobretudo a relação capital-trabalho, para garantir as condiçōes gerais da acumulação capitalista e da reprodução ampliada do capital(51). Acumulação de capital é condição para a existência e funcionamento do estado, e o estado é reproduzido pela acumulação de capital e dentro dela. $\Lambda$ exterioridade e autonomia relativa do estado face aos processos capitalistas de produçăo, troca e reprodução ampliada sảo criadas pelo próprio processo de acumulação capitalista. A separação formal do económico e do político é completa. A forma-estado é produto do capital e encontra-se numa relação para com os processos econômicos diferente daquela cm que se encontravam as formas de estado anteriores. Concretamente, isto implica um sistema internacional de estados que reproduzem as relaçóes capital-trabalho no plano do capital-trabalho assalariado, no plano das formas nāo-assalariadas de trabalho e no da relaçăo entre formas nāo-assalariadas e assalariadas, para assegurar as condiçốes de acumulação capitalista em escala mundial. Dentro desse sistema internacional de estados, o estado pode assumir uma série de formas concretas de organização, dependendo da relação de cada estado particular com a relação mundial entre capital-trabalho. Ao mesmo tempo, o contexto para a produção e reprodução das re-

48 Ver Marx, Capital, III, p. 328

49 Merrington, op. cit, p. 190.

50 Idem, ibidem, pp. 190-1.

51 Ver Joachim Hirsch. "The Stato Apparatus and Social Reproduc. tion: Elements of the Theory of the Bourgeois State", in Hollowny and Picciotto, State and Capital, p. 66. 
laçốes sociais do capital torna-se " nacional". Năo só a oposiçăo rural-urbano é reproduzida diferentemente, como também as relaçồes de desenvolvimento e subdesenvolvimento se manifestam como fenômenos "nacionais", determinados pela oposiçăo entre preços industriais e preços de bens primários, entre trabalho de alto custo e trabalho barato.

A emergência da produção capitalista como a forma dominante de trabalho social alterou fundamentalmente os processos que constituem a economia mundial e o papel da escravidão dentro deles. Durante o período de acumulação originária, a escravidăo deu impulso ao desenvolvimento do mercado mundial e da divisão internacional de trabalho. Contudo, a forma específica da produção escravista e o volume em que esta tinha sido estabelecida durante este primeiro período impediram-na de acompanhar, nas áreas mais antigas, as exigências de acumulação iniciadas com a transformaçảo capitalista da economia mundial. A contradição entre a produçăo escravista e a produção do trabalho assalariado livre durante este novo período expressou-se de modo mais agudo no Império Britânico(52). A produçăo escravista nas Antilhas inglesas havia sido orientada para uma organização préindustrial da produção e dependia de monopolios agora ultrapassados. A produtividade do trabalho escravo năo podia ser aumentada, e novas terras ou novos contingentes de escravos não eram ali disponíveis. Uma alternativa era estabelecer a produção escravista em áreas novas. Contudo, se as novas áreas de produção escravista (por exemplo, a Guiana Inglesa e Trinidad) fossem mantidas no quadro do antigo vínculo colonial de monopólio e restriçôes, a produçăo de excedente nas colonias mais antigas e menos produtivas estaria sendo subsidiada num contexto de relaçōes sociais anômalas. Por outro lado, se a força de trabalho fosse assegurada por outros meios nas novas áreas de produção, ainda neste caso estas prosperariam, e ficaria liberado o mecanismo de mercado de acumulação e reprodução ampliada na economia mundial.

O desenvolvimento do capitalismo industrial, inicialmente centrado na Inglaterra, criou condiçōes para a abolição da escravidão no Império Britânico e para que lá se estabelecessem novas relaçōes, consistentes com as novas exigências da acumulaçăo capitalista. Ao mesmo tempo, a revoluçâo industrial na Inglaterra resultou na expansâo e intensificação da escravidão fora do Império Británico, nảo como premissa histórica da produçăo capitalista, mas pressupondo a existência do capital industrial e sendo condiçăo para sua reprodução. A escravidão desenvolveu-se em escala maciça nos Estados Unidos, no Brasil e em Cuba como parte da nova divisão internacional capitalista do trabalho. O nexo de controle colonial direto rompeu-se e as relaçōes internacionais de produçăo passaram a ser determinadas pelo preço dos géneros produzidos pela mâo-de-obra escrava nestas regiōes.

A produçăo escravista agora se baseia na produção industrial e na "ilimitada sede de riquezas" do capital. Isto se reflete no volume e no caráter da produção escravista propriamente dita (veja-se por exemplo a introduçăo de nova tecnologia, como estradas de ferro e máquinas a vapor, e de novas relaçóes de produçāo em certos aspectos do processo do trabalho escravo)(53), na dimensăo e caráter do mercado para generos produzidos por escravos (incluindo-se aqui a substituiçăo do açúcar pelo algodåo como cultura predominante), $e$, finalmente, na introduçăo de gêneros produzidos por mâo-de-obra escrava diretamente no consumo da classe trabalhadora, como um aspecto tanto da manutenção da relação de troca entre capital e trabalho, quanto dos esforços sistemáticos para aumentar a produçăo de mais-valia através da redução dos custos de reprodução da força de trabalho. Assim, estas novas áreas escravistas encontram-se numa relaçăo para com a produçāo capitalista diferente daquela dos sistemas escravistas anteriores, e constituem um aspecto da acumulação do capital e de sua reprodução ampliada.

A produção especificamente capitalista de mercadorias e a forma assalariada do trabalho impōem agora sua marca na economia mundial como um todo, e esta se recompôe de acordo com as condiçôes de desenvolvimento daquelas. A relação capital-trabalho assalariado constitui-se de dentro de seus proprios processos, expande-se cada vez mais, e cria, como produto seu, outras formas de trabalho social. A reprodução ampliada da relação capital-trabalho assalariado recompōe internacionalmente a classe trabalhadora e redefine a relaçăo entre o trabalho assalariado e outras formas de trabalho social. A escravidão não é mais o pressuposto histórico da produçāo capitalista, isto é, condiçẫo para a emergência desta. Antes, a escravidāo reproduz-se como produto do capital e $e$ reconstituída dentro do desenvolvimento 
dos processos históricos de acumulaçáo capitalista e reprodução ampliada do capital. Ao mesmo tempo, a escravidão subsume-se como um momento subordinado da produçáo capitalista propriamente dita. Ela produz os elementos da produç̆o e reproduçáo capitalista e mantem-se como condição para a reproduçăo ampliada do capital.

O processo global de acumulação capitalista cria uma hierarquia mundial do trabalho através da imposiçáo da forma da mercadoria ao produto do trabalho e $\mathbf{a}$ propria força de trabalho. Todas as mercadorias e toda a produçăo de mercadoria são equiparadas à forma desenvolvida e complexa da mercadoria produzida pela relação capital-trabalho assalariado, que aparece agora como forma universal e elementar da riqueza, e são desenvolvidas através da valorização do capital. A produçăo de todo o trabalho é assim equiparada a produção do trabalho assalariado(54). A contradiçáo entre a produçáo escrava e a produçáo do trabalho assalariado e tanto intensificada quanto reproduzida em uma escala maior. $\mathbf{A}$ escravidão, mesmo nos novos centros de produçăo, $\ell$ incapaz de corresponder às exigências da acumulaçăo capitalista no contexto econठmico e político internacional que continua a transformar-se.

Neste ponto, é necessário enfatizar que os processos de recomposiçăo das rela. çôes entre trabalho e capital e das várias formas de trabalho social na economia mundial não são estritamente determinados por forças "econठmicas"; mas săo simultaneamente relaçóes de luta de classes, que assumem várias formas e săo mediadas por sua relação com a economia mundial e com o sistema internacional de estados. Os escravos nas Américas desenvolveram lutas autônomas para libertar-se da produção escravista de mercadorias e estabelecer um modo de organização social e economica independente. Os resultados de tais lutas não são simplesmente determinados pelo capital, mas pelo caráter das lutas propriamente ditas. Assim, em termos históricos concretos, a luta revolucionária dos escravos no Haiti virtualmente destruiu o império francés no Caribe e o principal sustentáculo do sistema colonial como um todo.

O problema para o capital é conter numa relação consigo mesmo estas novas formas de trabalho. Ainda quando o capital e bem-sucedido, essas lutas transformam as condiçóes de existencia do capital e de sua contínua acumulaçăo e, ao mesmo tempo, transformam as condiçóes de luta para todo o trabalho em toda a economia mundial capitalista. Com a formação de uma classe trabalhadora assala. riada na Europa, as lutas dos escravos nas Américas assumiram novo caráter e significado, que se distingue do que lutas semelhantes expressavam no periodo de acumulaçấo originária. As lutas escravas que agora ocorrem se relacionam com as lutas das recém-formadas classes trabalhadoras americana e européia, e de um ponto de vista ideologico foram transformadas pela doutrina de liberdade e igualdade(55). As lutas econðmicas e políticas do trabalho, tanto escravo como livre, se influenciaram reciprocamente; e sofreu um estreitamento significativo o espaço político, ideolo. gico e moral - assim como também o espaço económico - para a perpetuaçăo do regime escravo. Desse modo, as exigencias dinâmicas da acumulaçăo capitalista e o novo caráter das lutas de classe num mundo organizado em torno da relaçáo capital-trabalho assalariado levaram à dissolução final da escravidão e forçaram a emergência de novas formas de organizaçáo do trabalho.

A escravidão nas Américas deve ser compreendida em sua relaçăo com o desenvolvimento histórico da economia mundial capitalista como um todo, e analisada de acordo com categorias apropriadas a esse desenvolvimento. Nossa análise indica que a relação entre trabalho escravo e trabalho assalariado na economia mundial nảo pode ser vista como produto de um processo evolutivo linear, e sugere as relaçōes históricas complexas, múltiplas e qualitativamente distintas entre as duas formas de trabalho social. Durante o período de acumulação originária a escravidão foi constituída por um conjunto específico de relaçóes e processos sócio-históricos e desempenhou um papel particular na formação da economia mundial. Com a emergência da relação capital-trabalho assalariado e da acumulação capital ista como força organizadora da economia mundial, transformou-se o papel da escravidão no desenvolvimento capitalista. $\Lambda$ escravidão foi reconstituída por diferentes processos históricos e dentro de um conjunto de relaçōes sociais diferentes. Assim, tanto a história da escravidão nas Américas quanto a do trabalho assalariado na Europa devem ser compreendidas em sua relaçấo com o todo - o processo global de acumulação e as lutas contra esta acumulação - e não simplesmente em termos de suas proprias historias "internas".
54 Ver Marx, Capital, II, p. 113.

55 As lutas do trabalho escravo e do trabellho assalariado livre, ainda que marcadas por importantes dlferenças formais e distinçbes qualitativas, sto permendas de um contaúdo comum a tam como base comum sua relaça com o capital. A esse respelto, a revolu. cllo do Haiti 6 de importincla fundamental, nlo apenas como um ponto de inflexclo na historla des rebelibes escravas, mas tambern, como demonatrou C.LR Jarnes. devido a seu impacto no desernvol. virnento da rovoluphio francesa. Ner: Black Jacobins; Toussain L'Ouverture and the San Domingo Revolution, New York, 1963.) E necossirio mencionar tambim o estudo realizado por W.E.B. DuBols do modo como as lutas escravas contribuiram tanto para translormar o carbter soclal da Guerra de Secessito americana. quanto para apressar of fim desta. (Black Roconstruction in Americe, Cloveland, 1962.) A exposictio por estes dols pensedores do papel dos escravos africanos - seus descendentes nos processos que levaram aos mais avancedos tosultados da chilizacho moderna ainda 6 bem pouco apreciada. As lutas de escravos o trabalhadores assalariados sbo autonomas, freqûentemento antagónicas, mas inter-relacionadas; no mosmo ternpo que condiçoses, signiflcedos possibilidedes de luta estlio conbdos nes formas de organiraglo do trabalho social na conomia mundial. Marx sugere que ha uma tal relaçlo ontro as diferentes lutas e sua circulaçbo, por exemplo em: Capital, I, p. 414. 